Erlens Kalnin̦š, Dr. iur.

Latvijas Universitātes Juridiskā fakultāte, Latvija

\title{
REĀLNASTAS INSTITŪTA NOZĪME MŪSDIENU PRIVĀTTIESISKAJĀ APGROZĪBĀ
}

\section{IMPORTANCE OF REAL BURDEN INSTITUTE IN MODERN PRIVATE LEGAL CIRCULATION}

\begin{abstract}
Summary
This article is devoted to a rarely used property rights institute in Latvian practice - real burden (real charge), where the attention is drawn to the concept, essence and content of this institute. The purpose of the article is to describe the current and potential importance of the real burden in modern private legal circulation, illustrating it by typical examples from practice, which demonstrates, at the same time, the diversity and practical usefulness of the application of this property rights institute.
\end{abstract}

Atslēgvārdi: reālnasta, reālnastas izpildījumi, mūsdienu privāttiesiskā apgrozība

Keywords: real burden (real charge), performances of real burden, modern private legal circulation

\section{Ievads}

Civillikuma (turpmāk - CL) 1260.-1277. panta noteikumi, kas regulē reālnastas institūtu, pēc būtības negrozìtā veidā ir tikuši pārn,emti no attiecīgajiem 1864. gada Vietējo civillikumu kopojuma (turpmāk - VCL) 1297.-1321. panta noteikumiem. ${ }^{1}$ Pati "reālnasta" (Reallast, поземельнал повинность) CL 1260. pantā definēta kā "uz nekustamu īpašumu gulošs pastāvīgs pienākums atkārtoti dot noteiktus izpildījumus naudā, graudā vai klaušās”.

Raksturojot šo lietu tiesību institūtu, līdzšinējā Latvijas juridiskajā literatūrā ticis uzsvērts, ka reālnasta ir viduslaikos radies germān,u tiesību institūts, ${ }^{2}$ kas spilgti raksturo feodālo tiesību sistēmu, kuras centrā bija lietu tiesības, jo viduslaikos dažādas nodevas, klaušas un maksājumus bija ērtāk un izdevīgāk piesaistīt nekustamam īpašumam, nevis kādai personai. ${ }^{3}$ Reālnastas subjekta pienākuma pozitīvais raksturs vēsturiski ir

Sk.: Vietējo civillikumu kopojums (Vietējo likumu kopojuma III. daļa). Tieslietu ministrijas sevišķas komisijas sagatavojumā. Rīga: Valtera un Rapas akciju sab. izdevums, 1928, 156.-160. lpp.

2 Sk.: Čakste K. Civiltiesības. Lekcijas. Raksti. Rīga: Zvaigzne ABC, 2011, 122. lpp.; Rozenfelds J. Lietu tiesības. 4. izd. Riga: Zvaigzne ABC, 2011, 161.lpp.

3 Sk.: Višnnakova G., Balodis K. Latvijas Republikas Civillikuma komentāri. Lietas. Valdījums. Tiesības uz svešu lietu (841.-926., 1130.-1400. p.). Rīga: Mans İpašums, 1998, 148. lpp. (turpmāk CL komentāri / Balodis, 148. lpp.). 
izskaidrojams ar feodālā kunga un viṇa kalpa attiecībām, ${ }^{4}$ un vēl 19. gadsimta sākumā (līdz dzimtbūšanas atcelšanai) muižkungu un zemnieku attiecībās dažādām klaušām, kā arī izpildījumiem graudā (naturālijās) bija būtiska nozīme. ${ }^{5}$

Par reālnastas institūta praktisko izmantojumu jaunākajā juridiskajā literatūrā secināts, ka mūsdienu Latvijas juridiskajā praksē privātās reālnastas ir reti sastopamas, kaut arī to nodibināšana ir iespējama un var būt pat lietderīga (piem., lai nodrošinātu uztura saṇemšanu). ${ }^{6}$ Savukārt pēdējo gadu literatūrā, no vienas puses, izteikts priekšlikums paplašināt reālnastas institūta lietojumu praksē un ieviest likumisku reālnastu, kuras priekšmetu veidotu dzīvokḷa īpašuma katrreizējā īpašnieka pienākums regulāru naudas maksājumu veidā segt dzīvojamās mājas pārvaldī̌anas izdevumus un izdevumus par pakalpojumiem, kas saistīti ar dzīvokḷa īpašuma lietošanu. ${ }^{7}$ No otras puses, izteikts arī viedoklis, ka reālnasta ir ne tikai mūsdienu privāttiesiskajā apgrozībā maz izmantots lietu tiesību institūts, bet arī "arhaisks tiesību institūts", tādēḷ būtu jāizvērtē nepieciešamība to saglabāt Latvijas tiesībās, jo neesot "objektīva pamata civiltiesībās saglabāt šo feodālo tiesību institūtu esošajā veidolā".

N̦emot vērā minēto, raksta uzdevums ir "lauzt” atturīgo (un pat noraidošo) attieksmi pret reālnastas institūtu, raksturojot tā esošo un potenciālo nozīmi mūsdienu Latvijas privāttiesiskajā apgrozībā. Balstoties uz reālnastas (Reallast, Grundlast, onera realia) institūta izpratni Latvijā un citās germāṇu tiesību sistēmas valstīs (Vācijā, Austrijā, Šveicē), rakstā ar tipiskiem piemēriem no prakses tiks atspoguḷots reālnastas institūta izmantojuma daudzveidīgums un praktiskais noderīgums.

\section{Reālnastas jēdziens un būtība}

CL 1260. pantā reālnasta jēdzieniski definēta kā "uz nekustamo īpašumu gulošs pienākums" jeb kā liettiesisks apgrūtinājums, kura saturu veido šī nekustamā īpašuma katrreizējā īpašnieka pienākums "atkārtoti dot noteiktus izpildījumus naudā, graudā vai klaušās” par labu tiesīgajai personai. ${ }^{9}$ Ar reālnastu iespējams apgrūtināt vienīgi nekustamu īpašumu, kas var būt ne tikai zemesgrāmatā ierakstīts zemes gabals (ar visām tā sastāvdaḷām, sk. CL 968., 973., 1042. p.), bet arī zemesgrāmatā ierakstīts t. s. "ēku

4 Sk.: Sinaiskis V. Latvijas civiltiesību apskats. Lietu tiesības. Saistību tiesības. Rīga: Latvijas Juristu biedrība, 1996, 86. lpp.

5 Sk.: Blaese H., Mende S. Das Sachenrecht. Lettlands Zivilgesetzbuch vom 28. januar 1937 in Einzeldarstellungen. Bd II, 2. Riga: Verlag der AG “Ernst Plates”, 1940, S. 189, 190 (turpmāk Blaese / Mende, S. 189).

6 Sk.: CL komentāi / Balodis, 148., 149. lpp.

7 Sk.: Gulbis R. Pienākums segt dzīvojamās mājas pārvaldīšanas izdevumus un norēḳināties par pakalpojumiem, kas saistīti ar dzīvokḷa īpašuma lietošanu: reālnastas tiesiskā regulējuma attiecināšana kā risinājums. Grām.: Latvijas Republikas Satversmei - 95. Latvijas Universitātes 75. zinātniskās konferences rakstu krājums. Rīga: LU Akadēmiskais apgāds, 2017, 132. lpp. (turpmāk - Gulbis, 132. lpp.).

$8 \quad$ Sk.: Neilands R. Reālnastu arhaisms. Jurista Vārds, 06.03.2018., Nr. 10 (1016), 27., 28. lpp.

9 Sk.: CL komentāri / Balodis, 148., 149. lpp.; Sinaiskis V. Saimniecības tiesību lietiskās normas. Tieslietu Ministrijas Vēstnesis, 1935, Nr. 4, 720. lpp. (turpmāk - Sinaiskis, 720. lpp.). 
(būvju) nekustamais īpašums", ${ }^{10}$ dzīvokḷa īpašums ${ }^{11}$ vai apbūves tiesība. ${ }^{12}$ Izñēmuma kārtā ar reālnastu - līdzīgi kā ar hipotēku (sk. CL 1295. p.) - iespējams apgrūtināt arī nekustama ìpašuma kopīpašniekam piederošu domājamo daļu (sk. CL 1072. p.). ${ }^{13}$

No CL 1260. panta izriet, ka reālnasta kā subjektīva lietu tiesība piešķir tiesisku iespēju saņemt atkārtotus izpildijumus no apgrūtinātā jeb kalpojošā nekustamā īpašuma katrreizējā īpašnieka, kura pienākums savukārt ir atturēties no šis tiesības aizskaršanas un gādāt par reālnastas izpildījumu pienācīgu došanu tiesīgajai personai. Turklāt tiesīgã persona - līdzīgi kā servitūta tiesības gadījumā (sk. CL 1131.p.) var būt vai nu kāda noteikta fiziska, vai juridiska persona (t. s. "personālreālnasta", sk. CL 1263., 1265. p.), vai arī kāda cita nekustamā īpašuma katrreizējais īpašnieks (t. s. "prediālreālnasta", sk. CL 1263., 1264. p.). ${ }^{14}$

Jānem vērā, ka reālnastas tiesība - līdzīgi kā kịlas tiesība - ir liettiesiska iespēja "sañemt jeb piesavināties lietas vērtïbu" (Wertrecht, Verwertungsrecht, nраво присвоения), ${ }^{15}$ jo saskañā ar CL 1268. pantu "par reālnastas parādiem atbild nekustamais īpašums". Tas nozīmè, ka, no vienas puses, reālnastas tiesība kā tāda nepiešķir tiesīgajai personai iespēju prasības tiesvedības cel̦ā panākt no kalpojošā nekustamā īpašuma katrreizējā īpašnieka tādu izpildījumu došanu natūrā, kas neizpaužas kā naudas maksājumi. Tajā pašā laikā, no otras puses, šĩ tiesība piešķir tiesīgajai personai liettiesiski prioritāru iespēju par laikā nedotajiem (resp., nokavētajiem) izpildījumiem saņemt apmierinājumu no kalpojošā nekustamā īpašuma vērtỉbas jeb tās naudas summas, kas iegūta, vēršot piedziņu uz šo nekustamo īpašumu. ${ }^{16}$

Citiem vārdiem, ja reālnastas izpildījumi netiek labprātīgi doti, reālnastas tiesība piešķir tiesīgajai personai liettiesiski prioritāru iespēju - piedziņas vēršanas un kalpojošā nekustamā īpašuma piespiedu pārdošanas ceḷāa - saṇemt apmierinājumu par laikā nedotajiem izpildijjumiem jeb t. s. "reālnastas parādiem" no naudas summas, kas

10 Sk.: likuma "Par nekustamā īpašuma ierakstišsanu zemesgrāmatās" 13., 14., 26. pantu un likuma "Par atjaunotā Latvijas Republikas 1937. gada Civillikuma ievada, mantojuma tiesîbu un lietu tiesību dalas spēkā stāšanās laiku un piemērošanas kārtību" 14. panta pirmo daļu.

11 Sk.: Dzīvokḷa ipašuma likuma 2. panta pirmo dal̦u, 6. panta otro daļu un Zemesgrāmatu likuma 126. pantu.

12 Apbūves tiesība (sk. CL 1129.1 p. 1. d.) juridiskās fikcijas ceḷā ir pielīdzināta nekustamam īpašumam (sk. CL 1129.1 p. 2. d., 1129.5 p. 1. d.), un tā rodas ar ierakstišanu zemesgrāmatā (sk. CL 1129. ${ }^{3}$ p., Zemesgrāmatu likuma 55.1, 55.2 p.).

13 Sk.: Grūtups A., Kalniņš E. Civillikuma komentāri. Trešā daļa. Lietu tiesības. Īpašums. 2. izd. Rīga: Tiesu namu aǵentūra, 2002, 269. lpp.

14 Sk.: Blaese/Mende, S. 194; CL komentāri /Balodis, 151.-152. lpp.

15 Sal.: Sinaiskis, 721. lpp.; Vīnzarājs N. Lietu tiesïba. Tieslietu Ministrijas Vēstnesis, 1938, Nr. 2, 445. lpp.

16 Sal.: Gaier R. (red.). Münchener Kommentar zum Bürgerlichen Gesetzbuch. Bd. 7. Sachenrecht ( \$\$ 854-1296). WEG. ErbbauRG. 7. Aufl. München: Verlag C. H. Beck, 2017, \$ 1105, Rn. 7 (turpmāk - MüKoBGB / Mohr, $\$ 1105$, Rn. 7); Vieweg K., Werner A. Sachenrecht. 8. Aufl. München: Verlag Franz Vahlen, 2018, \$ 16, Rn. 73 (turpmāk - Vieweg / Werner, $\$ 16$, Rn. 73); Tuor P., Schnyder B., Schmid J., Jungo A. Das Schweizerische Zivilgesetzbuch. 14. Aufl. Zürich, Basel, Genf: Schulthess, 2015, $\mathbb{S} 110 \mathrm{~N} 5$ ff (turpmāk - Tuor / Schnyder / Schmid / Jungo, $\$ 110$ N 5); Schmid J., Hürlimann-Kaup B. Sachenrecht. 5. Aufl. Zürich, Basel, Genf: Schulthess, 2017, N 1445, 1452a (turpmāk - Schmid / Hürlimann-Kaup, N 1445); Koziol H., Bydlinski P., Bollenberger R. (Hrsg.) Kurzkommentar zum ABGB. 5. Aufl. Wien: Verlag Österreich, 2017, \$ 530, Rz 6 (turpmāk - Koch in $\mathrm{KBB}$, \$ 530, Rz 6). 
saņemta par šī nekustamā īpašuma pārdošanu izsolē (sk. CL 1268. p.), turklāt atbilstoši prasījumu apmierināšanas secībai, kas paredzēta Civilprocesa likuma (turpmāk - CPL) 628. panta pirmajā dalāā. ${ }^{17}$ Protams, šāda piedzina var notikt vienīgi uz izpildu dokumenta pamata (sk. CPL 540. p.). Tāpēc strīda gadījumā tiesīgā persona parasti ir spiesta vispirms celt tiesā prasību par uzkrājušos "reālnastas parādu" piedziṇu naudā, ${ }^{18}$ lai uz attiecīga tiesas sprieduma pamata saņemtu izpildu rakstu un to iesniegtu piespiedu izpildei, un lai tādējādi panāktu piedziņas vēršanu uz kalpojošo nekustamo īpašumu. ${ }^{19}$

Reālnastas būtību un praktisko lietderību spilgti raksturo tās liettiesiskā noturība, jo kalpojošā nekustamā īpašuma "pārdošana izsolē neizbeidz uz to gulošo reālnastu” (sk. CL 1262. p.), un tā "pāriet uz pircēju” (sk. CL 2088. p.), resp., "uz katru šì nekustamā īpašuma ieguvēju” (sk. CL 1261. p.). Atbilstoši minētajām normām arī piedziņas vēršana uz kalpojošo nekustamo īpašumu un tā pārdošana piespiedu izsolē pēc vispārīgā principa neizbeidz reālnastu. ${ }^{20}$ Tāpēc, apstiprinot nekustamā īpašuma izsoles aktu, zemesgrāmatā nostiprinātā reālnasta - atškirīibā no hipotēkām vai kūlas tiesības atzīmēm kā zemesgrāmatā ierakstītām "parādu saistībām” - nav dzēšama (sk. Civilprocesa likuma 613. p. 5. d.) un turpina apgrūtināt nekustamo īpašumu. ${ }^{21}$ Izñēmuma kārtā reālnasta var tikt dzēsta, ja tā tikusi nostiprināta zemesgrāmatā pēc hipotēkas nostiprināšanas, turklāt bez hipotekārā kreditora piekrišanas (sk. CL 1317. p.), un ja šì iemesla dēl hipotekārais kreditors ir pieprasījis t. s. "divkāršo izsoli” (sk. CPL 609. p.). Proti, ja nekustamais īpašums ticis pārdots divkāršã izsolē ar nosacījumu, ka reālnasta

${ }^{17}$ Ja kalpojošais nekustamais īpašums ir apgrūtināts kā ar reālnastu, tā arī ar hipotēku, reālnastai ir prioritāte pār hipotēku, proti, no naudas summas, kas saņemta par šī nekustamā īpašuma pārdošanu izsolē, "reālnastas parādi" ir apmierināmi pirms to prasījumu apmierināšanas, kas nodrošināti ar hipotēku (sk. CPL 628.p. 1.d. 3. un 4. pk.).

18 Šì iemesla dẹl tiem reālnastas izpildījumiem, kas neizpaužas kā naudas maksājumi, jābūt ar naudā nosakāmu vērtību (sal.: MüKoBGB / Mohr, $\mathbb{S} 1105$, Rn. 13, 32), lai prasības tiesvedības kārtībā piedzenamo "reālnastas parādu" apmēru varētu aprēķināt naudā, jo, vēeršot piedziņu uz nekustamo īpašumu, iespējams apmierināt vienīgi naudā izteiktus prasījumus. Tā, piem., ja reālnastas priekšmets ir pastāvīgs pienākums tĩrìt ielu citā nekustamajā īpašumā, nokavēto izpildījumu vērtība nosakāma un aprēkināma naudā atbilstoši minēto tīrīšanas darbu attiecīgā brǐža tirgus cenai, sk.: Augstākās tiesas 1929. gada 27. februāra spriedums Nr. 167. Latvijas Senāta spriedumi (1918-1940). 11. sēj. Senāta Civilā kasācijas departamenta spriedumi (1928-1929). Faksimilizdevums. Rīga: Latvijas Republikas Augstākā tiesa, Senatora Augusta Lēbera fonds, 1998, 4484.-4485. lpp.

19 Kā izpildu dokuments var kalpot arī, piem., tiesneša lēmums par saistību bezstrīdus piespiedu izpildī̌anu vai notariālais izpildu akts (sk. CPL 540. p. 4. un 16. pk.), ja ar reālnastu nodrošinātais un zemesgrāmatā nostiprinātais pienākums atkārtoti un noteiktos termiņos veikt naudas maksājumus izriet no notariāla akta formā taisīta līguma (sk. CPL 400. p. 1. d. 2. pk., Notariāta likuma 107. ${ }^{1}$ p. 1. un 3. pk.).

20 Sk.: Blaese/Mende, S. 194; Augstākās tiesas 1934. gada 23. februāra spriedums Nr. 619. X Izvilkumi no Latvijas Senāta Civilā kasācijas departamenta spriedumiem. Sastādījuši: senators F. Konradi un Riggas apgabaltiesas loceklis A. Valters. Riga: izdevnieciba "Jurists" / izdevniecỉba "Grāmatrūpnieks", 1933/1934, 287. lpp.; Konradi F., Valters A. (sast.). Civilllikumi ar paskaidrojumiem. Otrā grāmata. Lietu tiesības. Rīga: "Grāmatrūpnieks" izdevums, 1935, 291. lpp. (turpmāk - Konradi / Valters, 291. lpp.).

21 Sk.: CL komentāri/Balodis, 151. lpp.; Augstākās tiesas 1938. gada 24. maija spriedums Nr. 475. Latvijas Senāta spriedumi (1918-1940). 14. sēj. Senāta Civilă kasācijas departamenta spriedumi (1937-1940). Faksimilizdevums. Rīga: Latvijas Republikas Augstākā tiesa, Senatora Augusta Lēbera fonds, 1998, 5547.-5548. 1рр.; Буковский В. (сост.). Сводъ гражАанскихъ узаконений губерний Прибалтийскихъ (съ продомжениемъ 1912-1914 г. г. и съ разъяснениями въ 2 томахъ). Т. ІІ. Право требований. Рига: Г. Гемпель и Ко, 1914, с. 1715, 1716. 
dzēšama (sk. CPL 609. p. 3. un 4. d.), tad, apstiprinot izsoles aktu, šis liettiesiskais apgrūtinājums tiek dzēsts (sk. CPL 615.p. 5. d. 3.pk.). ${ }^{22}$

\section{Latvijas situācija}

Raksturojot reālnastas institūta līdzšinējo praktisko lietojumu Latvijā, pirmām kārtām jānorāda, ka gan juridiskajā literatūrā, kas veltīta VCL 1297.-1321. pantā resp. CL 1260.-1277. pantā regulētajam reālnastas institūtam, gan pieejamajā tiesu praksē atrodama salīdzinoši skopa informācija par to, kādās tiesiskajās attiecībās privāttiesiskās apgrozības subjektiem var būt interese nodibināt reālnastu un kādās tieši darbībās (t. i., atkārtoti dodamos izpildījumos) var izpausties reālnastas priekšmets vienā vai otrā no šīm praksē sastopamajām dzīves situācijām. Tajā pašā laikā minētā (lai arī skopā) informācija faktiski ietver un atspoguḷo visus galvenos juridiskos aspektus, kuri raksturīgi reālnastas institūta praktiskajam lietojumam, kāds vērojams mūsdienu privāttiesiskajā apgrozībā citās germāṇu tiesību sistēmas valstīs.

Tā 19. gadsimta beigu juridiskajā literatūrā kā viens no privātas reālnastas izmantošanas pamatgadijumiem minēts t. s. rentes pirkums (Rentenkauf), ${ }^{23}$ ar ko tika saprasta kapitāla aizdošana, kā pretizpildījumu "nopērkot” ikgadējus rentes maksājumus, kuri dodami no nekustamā īpašuma ienākumiem un kuru došana nodrošināta ar attiecīgas reālnastas nostiprināšanu uz šo nekustamo īpašumu. ${ }^{24}$

Attīstot tālāk domu par reālnastu kā lietu tiesību, ar ko iespējams liettiesiski nodrošināt saistībtiesiskus prasījumus par atkārtotu izpildījumu saņemšanu, juridiskajā literatūrā uzsvērts, ka principā "katru prasījumu var pārvērst par reālnastas prasījumu" (arī prasījumu par uztura saņemšanu). ${ }^{25}$ Tā, piem., ar nekustamā īpašuma atsavinājuma līgumu var nodibināt reālnastu, lai "nodrošinātu turpmāko uzturu", ${ }^{26}$ resp., lai ar zemesgrāmatā nostiprināto reālnastu liettiesiski nodrošinātu atsavinātāja uztura prasījumu pret nekustamā īpašuma ieguvēju kā uztura devēju (sk. CL 2096., 2098. p.). Jaunākā tiesu prakse apliecina, ka reālnasta var kalpot arī kā līdzeklis, lai nodrošinātu no nekustamā īpašuma pirkuma līguma izrietošo pārdevēja prasījumu par pirkuma maksas saṇemšanu regulāru ikmēneša maksājumu veidā. ${ }^{27}$

Par cita veida izpildījumiem tiesu praksē un juridiskajā literatūrā atzīts, ka reālnastas priekšmets var būt, piem., dzirnavu īpašnieka pastāvīgs pienākums malt labības

22 Sk.: Blaese /Mende, S. 194; Konradi F., Zvejnieks T. (sast.). Civilprocesa likums (1938. g. izd., 1939. g. iespied.) ar paskaidrojumiem. Rïga: Valsts tipogräfijas izdevums, 1939, 373.-375. lpp.

23 Sk.: Erdmann C. System des Privatrechts der Ostseeprovinzen Liv-, Est- und Curland. Bd. II. Sachenrecht. Riga: N. Kymmel's Verlag, 1891, S. 509, Fn. 3, S. 522 (turpmāk - Erdmann, S. 509).

24 Sk.: von Bunge F. G. Das liv- und esthländische Privatrecht. Theil I: Einleitung, Personen-, Sachen- und Forderungenrecht. 2. Aufl. Reval: Verlag von Franz Kluge, 1847, S. 296; Erdmann, S. 509, Fn. 3.

25 Sk.: Vīnzarājs N. Lietu tiesība. Tieslietu Ministrijas Vēstnesis, 1938, Nr. 2, 442.-443. lpp.

26 Sk.: CL komentāri /Balodis, 149. lpp.; Gulbis, 130. lpp.

27 Sk.: Rīgas apgabaltiesas 2018. gada 10. maija spriedums lietā Nr. C31362815, 1., 11. punkts. Pieejams: https://manas.tiesas.lv/eTiesasMvc/nolemumi. 
graudus par labu citai personai, ${ }^{28}$ zemes gabala īpašnieka pienākums katru gadu sacirst un izvest no meža cita nekustamā īpašuma apkurināšanai nepieciešamo daudzumu malkas, ${ }^{29}$ ar pirkuma līgumu nodibināts nopirktā nekustamā īpašuma pircēja pastāvīgs pienākums tīrìt ielu citā, t. i., pārdevējam piederošajā nekustamajā īpašumā, ${ }^{30}$ zemes gabala īpašnieka pienākums žogot kopīgo ganu cel̦u, ciktāl tas sniedzas gar viņa zemes gabalu, kā arī pastāvīgs pienākums attiecīgo žoga dalı uzturēt un izlabot, ${ }^{31}$ ipašnieka pienākums viņa nekustamajā īpašumā saražoto elektroenerǵiju vai iegūto dzeramo ūdeni pastāvīgi piegādāt cita nekustamā ìpašuma izmantošanas vajadzībām, ${ }^{32}$ lauku saimniecības īpašnieka pienākums šajā saimniecībā iegūtos lauksaimniecības produktus regulāri piegādāt citai personai. ${ }^{33}$

Jaunākajā juridiskajā literatūrā un praksē secināts, ka ēku (būvju) nekustamā īpašuma katrreizējā īpašnieka likumiskais pienākums maksāt piespiedu nomas maksu par labu attiecīgā zemes gabala katrreizējam īpašniekam atbilst reālnastas pazìmēm. ${ }^{34}$ Kā atzinusi Augstākā tiesa, uz likuma pamata pastāvošo tiesību saṇemt piespiedu nomas maksu var nostiprināt zemesgrāmatā kā lietu tiesību, kas apgrūtina ēku (būvju) nekustamo īpašumu, turklāt pēc attiecīgā zemes gabala īpašnieka vēlēšanās (sk. Zemesgrāmatu likuma 5. p.), ja ar īpašnieku starpā noslēgto piespiedu nomas lìgumu ticis konkretizēts uz likuma pamata viṇu starpā pastāvošo piespiedu nomas attiecību saturs. ${ }^{35}$ No jaunākās zemesgrāmatu nodaļu prakses turklāt redzams, ka ar ligumiski nodibinātu reālnastu tiek nodrošināts neapbūvēta vai jau apbūvēta zemes gabala katrreizējā īpašnieka pienākums maksāt ikmēneša apsaimniekošanas maksu (apkalpošanas maksu) par labu cita nekustamā īpašuma katrreizējam īpašniekam, kurš gādā par attiecīgā privātmāju ciemata koplietošanas teritorijas, kā arī infrastruktūras uzturēšanu un apsaimniekošanu. ${ }^{36}$

28 Sk.: Буковский В. (сост.). Сводъ гражАанскихъ узаконений губерний Прибалтийскихъ (съ продолжениемъ 1912-1914 г. г. и съ разъяснениями въ 2 томахъ). Т. І. Введение, Право семейственное, Право вещное и Право наследования. Рига: Г. Гемпель и Ко, 1914, с. 520.

29 Sk.: Тютрюмовъ И. М. ГражАанское право. ИзА. 2. Тарту: Типография Г. Ааакманъ, 1927, с. 233, прим. 4.

30 Sk.: Augstākās tiesas 1929. gada 27. februāra spriedums Nr. 167. Latvijas Senāta spriedumi (19181940). 11. sēj. Senāta Civilā kasācijas departamenta spriedumi (1928-1929). Faksimilizdevums. Rīga: Latvijas Republikas Augstākā tiesa, Senatora Augusta Lēbera fonds, 1998, 4484.-4485. lpp.; sk. arī: Konradi / Valters, 293.-294. lpp.

31 Sk.: Augstākās tiesas 1933. gada 13. decembra spriedums Nr. 930. X Izvilkumi no Latvijas Senāta Civilā kasācijas departamenta spriedumiem. Sastādījuši: senators F. Konradi un Rỉgas apgabaltiesas loceklis A. Valters. Rīga: izdevniecỉba “Jurists" / izdevniecība “Grāmatrūpnieks”, 1933/1934, 159.-160.lpp.

32 Sk.: CL komentāri / Balodis, 151. lpp.; Gulbis, 130. lpp.

33 Sk.: CL komentāri / Balodis, 149., 151.lpp.

34 Sk.: Rozenfelds J. Pētījums par Civillikuma Lietu tiesību daļas (ceturtās, piektās, sestās un septītās nodaḷas) modernizācijas nepieciešamību (2008), 5.-6. lpp. Pieejams: http://at.gov.lv/lv/resursi/ petijumi.

35 Sk.: Augstākās tiesas Senāta 2012. gada 4. oktobra lēmums lietā Nr. SKC-1702/2012 (C01199611) un Augstākās tiesas Civillietu tiesu palātas 2012. gada 11. decembra lēmums lietā Nr. C01199611. Nav publicēti.

36 Sk.: Neilands R. Reālnastu arhaisms. Jurista Vārds, 06.03.2018., Nr. 10 (1016), 27. lpp. 


\section{Reālnastas satura vispārējs raksturojums}

Pirms pievērsties konkrētu tipisku (šoreiz galvenokārt ārvalstu) prakses piemēru apskatam, ìsumā nepieciešams vispārēji raksturot CL 1260. pantā noregulēto reālnastas saturu.

Saskañā ar CL 1260. pantu reālnastas izpildījumiem, pirmkārt, jāizpaužas aktīvās jeb pozitīvās darbībās (devumos), ${ }^{37}$ un ar šo pazīmi reālnasta principiāli atšķiras no reālservitūta kā liettiesiska apgrūtinājuma (sk. CL 1141.-1189. p.), kura tipisko saturu veido kalpojošā nekustamā īpašuma katrreizējā īpašnieka pienākums vai nu atturēties no zināmām darbībām, ${ }^{38}$ vai arī paciest, ka zināmas darbības izdara servitūta izlietotājs (vienīgo izṇēmumu sk. CL 1175. p.). ${ }^{39}$ Turklāt pozitīvajām darbībām, kuru liettiesiskai nodrošināšanai kalpo reālnasta, jābūt novērtējamām naudā, lai tiesīgajai personai būtu iespēja saņemt apmierinājumu par "reālnastas parādiem" no naudas summas, kas saņemta, vēršot piedziņu uz kalpojošo nekustamo īpašumu (pēc vispārīgā principa naudā novērtējami ir arī personiski izpildāmi pakalpojumi, piem., personas aprūpēšana un uzraudzī̌sana)..$^{40}$

Otrkārt, pretēji juridiskajā literatūrā paustajam viedoklim par reālnastas izpildījumu "mūžīgumu" ("pastāvīgumu”) un neiespējamību nodibināt laika ziṇā ierobežotu reālnastu, ${ }^{41}$ mūsdienu privāttiesiskās apgrozības vajadzībām atbilstošāks ir uzskats, ka reālnastu iespējams nodibināt ne tikai uz nenoteiktu laiku, bet arī uz noteiktu laiku, kas var būt aprobežots ar beigu terminu vai nosacijumu (piem., ar tiesīgās personas dzīves ilgumu). ${ }^{42}$ Nepiel̦aujot reālnastas nodibināšanu uz noteiktu laiku, neattaisnoti tiktu ierobežota personu privātautonomija un reālnastas institūts daudz mazāk būtu piemērots saistībtiesisku prasījumu nodrošināšanas mērḳim.

Treškārt, reālnastas izpildījumiem jābūt tādiem, kas dodami "atkārtoti”, taču tiem nav obligāti jāatkārtojas regulāri jeb iepriekš precīzi noteiktos termiņos. Arī ilgstoši vai pastāvīgi izpildījumi (piem., būves vai iekārtas uzturēšana kārtībā, elektroenerǵijas vai ūdens piegāde) ir uzskatāmi par atkārtotiem izpildījumiem. ${ }^{43}$ Turklāt nav nepieciešams,

37 Sk.: Sinaiskis, 720. lpp.

38 Tāpēc par reālnastas priekšmetu nevar būt, piem., apbūvēta zemes gabala katrreizējā īpašnieka vispārējs "pienākums ievērot [privātmāju ciemata] teritorijas lietošanas noteikumus", jo tas var ietvert arī pienākumu atturēties no zināmām darbībām, sal.: Augstākās tiesas 2014. gada 30. janvāra lēmums lietā Nr. SKC-1479/2014, 7. punkts. Pieejams: http://at.gov.lv/lv/judikatura/judikaturas-nolemumu-arhivs.

39 Sk.: Blaese/Mende, S. 189; CL komentāri / Balodis, 149. lpp.

40 Sal.: MüKoBGB / Mohr, $\mathbb{S} 1105$, Rn. 13; Palandt O. (Begr.) Bürgerliches Gesetzbuch. 78. Aufl. München: Verlag C. H. Beck, 2019, \$ 1105, Rn. 4 (turpmāk - Palandt/Herrler, $\mathbb{~ 1 1 0 5 , ~ R n . ~ 4 ) . ~}$

${ }^{41}$ Sk.: Erdmann, S. 510, 513; Konradi / Valters, 287. lpp.; Blaese / Mende, S. 189; CL komentāri / Balodis, 150. lpp.; Rozenfelds J. Lietu tiesības. 4. izd. Riga: Zvaigzne ABC, 2011, 161. lpp.

42 Sk.: Gulbis, 130. lpp.; sal.: MüKoBGB / Mohr, $\$ 1105$, Rn. 20; Prütting H. Sachenrecht. 36. Aufl. München: Verlag C. H. Beck, 2017, Rn. 943; Binder M. Sachenrecht. Wien: Verlag Österreich, 2003, Rz 9/5 (turpmāk - Binder, Rz 9/5; Iro G. Sachenrecht. 6. Aufl. Wien: Verlag Österreich, 2016, Rz 16/2 (turpmāk - Iro, Rz 16/2); Kostkiewicz J. K., Wolf S., Amstutz M., Fankhauser R. (Hrsg.) ZGB Kommentar. 3. Aufl. Zürich: Orell Füssli Verlag, 2016, Art. 782, N 11 (turpmāk ZGB Kommentar/Flück, Art. 782, N 11).

43 Sk.: CL komentāri / Balodis, 150.-151. lpp.; Gulbis, 130. lpp. 
lai visiem reālnastas izpildījumiem būtu vienāds veids vai apmērs, proti, no vienas reālnastas izrietošajiem atkārtotajiem izpildījumiem var būt arī atškkirīgs veids vai apmērs. ${ }^{44}$

Ceturtkārt, raksturojot reālnastas izpildijjumu pamatveidus, CL 1260. pantā vecmodīgā formulējumā noteikts, ka reālnastas izpildījumi var tikt doti "naudā, graudā vai klaušās”. No mūsdienu viedokḷa šis formulējums nozimē to, ka reālnastas izpildījumi var izpausties kā naudas maksājumi, kā dažādu lietu (naturāliju) devumi vai arī kā darba veikšana (pakalpojumu sniegšana) tiesīgās personas labā. ${ }^{45}$

Piektkārt, CL 1260. p. ietvertā norāde uz to, ka reālnastas izpildījumiem jābūt "noteiktiem”, nenozīmē, ka atsevišķiem izpildījumiem jau iepriekš jābūt noteiktiem pilnīgi precīzi (piem., konkrētas naudas summas veidā). Tajā pašā laikā tomēr nepieciešams, lai atkārtoti dodamie izpildījumi būtu nosakāmi. Citiem vārdiem, no zemesgrāmatā izdarītā reālnastas nostiprinājuma, resp., no tiesiskā darījuma, uz kura pamata izdarìts šis nostiprinājums, pietiekami skaidri jāizriet, atbilstoši kādiem (objektīvi pārbaudāmiem) apstākḷiem ir nosakāms atsevišķo izpildijumu veids un apmērs. Turklāt trešajām personām (piem., kreditoriem, kuru prasijjumiem ir zemāka prioritāte) jābūt iespējai noteikt iespējamo reālnastas maksimālo apmēru (tā, piem., ja reālnastas saturu veido pienākums uzturēt un apsaimniekot kādu būvi, šì apgrūtinājuma maksimālo iespējamo apmēru veido visu minētā pienākuma izpildei nepieciešamo izdevumu summa visnelabvēlīgākajā situācijā). ${ }^{46}$ Minētais vienlaikus nozīmē, ka reālnastas saturu var veidot izpildījumi ar mainīgu apmēru, ${ }^{47}$ un šajā ziņā reālnastai var tikt piesaistīta arī t. s. "vērtības nodrošināšanas klauzula" (piem., izdarot norādi uz "patēriṇa cenu indeksu" un pielīgstot, ka šī indeksa izmaiņas automātiski ietekmē arī turpmāk dodamo reālnastas izpildījumu apmēru). ${ }^{48}$

Jāpiebilst, ka atbilstoši zemesgrāmatu publicitātes principam nepieciešams, lai no attiecīgā zemesgrāmatas nostiprinājuma izrietētu tas, ka ir tikusi nostiprināta "reālnasta”, turklāt šim nostiprinājumam trāpiga formulējuma veidā koncentrēti jāatspogulo attiecīgās reālnastas saturs. ${ }^{49}$ Ja reālnastai piesaistīta "vērtības nodrošināšanas klauzula", arī šim apstāklim pietiekami skaidri jāizriet no reālnastas nostiprinājuma vai tiesiskā darījuma, uz kura pamata izdarīts šis nostiprinājums. ${ }^{50}$

\section{Reālnastas institūta praktiskais lietojums}

N̦emot vērā reālnastas institūta izpratni Latvijā un citās germāṇu tiesību sistēmas valstīs (Vācijā, Austrijā, Šveicē), nobeigumā atlicis raksturot šì lietu tiesību institūta

${ }^{4}$ Sal.: MüKoBGB / Mohr, $\$$ 1105, Rn. 23 f; Iro, Rz 16/2; Koch in KBB, $\$ 530$, Rz 2.

45 Sk.: CL komentāri / Balodis, 151. lpp.; Gulbis, 131.lpp.

46 Sk.: Gulbis, 131.lpp.; sal.: MüKoBGB /Mohr, $\$ 1105$, Rn. 32; Vieweg/Werner, $\$ 16$, Rn. 74.

47 Sk.: Gulbis, 131.lpp.

48 Sal.: MüKoBGB / Mohr, $\$ 1105$, Rn. 32 ff.; Palandt / Herrler, $\$ 1105$, Rn. 6; Koch in KBB, $\$ 530$, Rz 3.

49 Sal.: MüKoBGB /Mohr, $\$ 1105$, Rn. 64; Demharter J. Grundbuchordnung. 31. Aufl. München: Verlag C. H. Beck, 2018, \$ 44, Rn. 17; Zobl D. Grundbuchrecht. 2. Aufl. Zürich, Basel, Genf: Schulthess, 2004, N 294; Iro, Rz 16/5.

so Sal.: MüKoBGB / Mohr, $\$ 1105$, Rn. 34, 64. 
nozīmi mūsdienu privāttiesiskajā apgrozībā, to ilustrējot ar tipiskiem piemēriem no prakses, kas vienlaikus uzskatāmi atspoguḷo arī reālnastas institūta izmantojuma daudzveidīgumu un praktisko noderīgumu.

Raksturojot reālnastas institūta praktisko lietojumu, parasti tiek uzsvērta reālnastas piemērotība saistībtiesisku prasījumu (resp., šādiem prasījumiem atbilstošo saistību izpildī̌̌anas) liettiesiskai nodrošināšanai. ${ }^{51}$ Šajā ziņā kā klasisks piemērs kalpo reālnasta, ar ko apgrūtināts par labu uztura devējam atsavinātais nekustamais īpašums, nodrošinot no uztura līguma izrietošos uztura ņēmēja prasījumus par uztura saṇemšanu. Šãdas reālnastas izpildijjumi parasti izpaužas kā uztura došana ikmēneša maksājumu un/vai naturāliju veidā, kā uztura ņēmēja personiska aprūpēšana vai šādas aprūpes izdevumu segšana. Ar uztura līgumu bieži vien tiek nodibināta uztura ņēmēja dzīvokḷa tiesība uz kalpojošo nekustamo īpašumu (šo tiesību nostiprinot zemesgrāmatā kā personālservitūtu), tāpēc reālnastas priekšmets parasti ietver arī pienākumu uzturēt (apsaimniekot) attiecīgo dzìvokli, kā arī segt visus ar to saistītos izdevumus. ${ }^{52}$

Tāpat iespējams liettiesiski nodrošināt arī prasījumus (t. sk. blakus prasījumus) par atkārtoti dodamu izpildījumu saṇemšanu, kas izriet no cita veida atsavinājuma līgumiem, piem., no pirkuma līguma (ar reālnastu, kas nostiprināta uz pārdoto nekustamo īpašumu, nodrošinot pārdevēja prasījumu par pirkuma maksas saṇemšanu regulāru ikmēneša maksājumu veidā, un vienlaikus arī nodibinot pārdevēja dzìvokḷa tiesību uz minētā nekustamā īpašuma daḷu ${ }^{53}$ vai no aizdevuma līguma (ar reālnastu, kas nostiprināta uz aizṇēmējam piederošu nekustamo īpašumu, nodrošinot aizdevēja prasījumus par aizdevuma kapitāla atdošanu kopā ar procentiem). ${ }^{54}$

Ar reālnastu, kuras izpildījumus veido naudas maksājumi, var tikt nodrošināts ne tikai zemes gabala īpašnieka prasijums pret ēku (būvju) nekustamā īpašuma īpašnieku (vai dzivvokḷa īpašumu īpašniekiem) par piespiedu nomas maksājumu saṇemšanu (nostiprinot attiecīgu reālnastu uz ēku (būvju) nekustamo īpašumu vai dzivokḷa īpašumiem), ${ }^{55}$ bet arī, piem., ar reālservitūtu apgrūtinātā nekustamā īpašuma īpašnieka prasījums pret servitūta izlietotāju par savstarpēji nolīgtās atlīdzības saṇemšanu atkārtotu maksājumu veidā (nostiprinot attiecīgu reālnastu uz nekustamo īpašumu, kuram par labu nodibināts reālservitūts), vai, piem., ar apbūves tiesību apgrūtinātā zemes gabala īpašnieka prasījums pret apbūves tiesīgo par pielīgtās maksas (sk. CL 1129. ${ }^{2}$ p. 1. d., $1129 .{ }^{6}$ p. 1. d.) saṇemšanu atkārtotu maksājumu veidā (nostiprinot attiecīgu reālnastu uz zemesgrāmatā ierakstīto apbūves tiesību). ${ }^{56}$

51 Sk.: MüKoBGB / Mohr, $\$ 1105$, Rn.2, 4, 66; Palandt / Herrler, vor $\$ 1105$, Rn. 1; Tuor / Schnyder / Schmid / Jungo, \$ 110 N 2, 9; Koch in KBB, \$ 530, Rz 3.

52 Sk.: Weber R. Sachenrecht II. Grundstücksrecht. Baden-Baden: Nomos Verlagsgesellschaft, 2005, \$ 20, Rn. 2; Vieweg/Werner, $\ 16$, Rn. 72; MüKoBGB / Mohr, $\$ 1105$, Rn. 2, 46 ff; Koch in KBB, $\ 530$, $\mathrm{Rz} 4$; Iro, Rz 16/9 f; Binder, Rz 9/5.

53 Sk.: Rīgas apgabaltiesas 2018. gada 10. maija spriedums lietā Nr. C31362815, 1., 11. punkts. Pieejams: https://manas.tiesas.lv/eTiesasMvc/nolemumi.

54 Sal.: MüKoBGB / Mohr, \$ 1105, Rn. 26.

55 Sk.: Augstākās tiesas Senāta 2012. gada 4. oktobra lēmums lietā Nr. SKC-1702/2012 (C01199611) un Augstākās tiesas Civillietu tiesu palātas 2012. gada 11. decembra lēmums lietā Nr. C01199611. Nav publicēti.

56 Sal.: MüKoBGB / Mohr, $\$ 1105$, Rn. 3; Iro, Rz 16/2, 17/3. 
Reālnastas izpildījumi var izpausties ne tikai kā naudas maksājumi, bet arī kā dažādu lietu (naturāliju) devumi par labu tiesīgajai personai, piem., kā derīgo izrakteņu, lauksaimniecības vai mežsaimniecības produktu piegāde (dzeramā ùdens piegāde no ūdens ieguves vietas, ${ }^{57}$ cukurbiešu piegāde cukurfabrikai, ${ }^{58}$ kartupel̦u vai labības piegāde ${ }^{59}$ malkas piegāde ${ }^{60}$ ), kā elektroenerğijas vai siltumenerğijas piegāde (no energijas ražotnes). ${ }^{61}$

Visbeidzot, reālnastas izpildījumi var izpausties kā zināma darba veikšana, resp., pakalpojumu sniegšana tiesīgās personas labā. Turklāt ar šādiem izpildījumiem saprotama ne tikai personas aprūpēšana un uzraudzǐšana (t. sk. aprūpējamas personas kopšana), ${ }^{62}$ bet arī cita veida pakalpojumu sniegšana (t. sk. attiecīga apkalpojošā personāla, piem., personu aprūpētāja, telpu apkopēja, sētnieka, nodrošināšana) un ar šādu pakalpojumu sniegšanu saistīto izdevumu segšana. ${ }^{63}$ Tādējādi reālnastas izpildījumi var izpausties kā noteiktas teritorijas, būves vai iekārtas uzturēšana (apsaimniekošana) un ar to saistīto izdevumu segšana, piem., kā kalpojošā nekustamā ìpašuma katrreizējā īpašnieka pienākums uzturēt kalpojošajā vai citā (valdošajā) nekustamajā īpašumā esošu ceļu (kājcel̦u, ielu), mūri (sētu), dzīvžogu, dambi, tiltu (pārbrauktuvi), kapus (kapa vietas), ${ }^{64}$ kā pienākums saglabāt kalpojošā nekustamā īpašuma stāvokli, uzturot (apsaimniekojot) un/vai ekspluatējot tajā esošu būvi vai iekārtu ${ }^{65}$ (pazemes garāžas vai pārceltuves uzturēšana un ekspluatācija), ${ }^{66}$ kā kokzāgètavas nekustamā īpašuma katrreizējā īpašnieka pienākums zāgèt malku vietējās pašvaldības labā (par izdevīgu cenu), ${ }^{67}$ kā "brīvdienu mītṇu" nekustamā īpašuma katrreizējā īpašnieka pienākums par labu tiesīgajai personai (patērētājam) apsaimniekot un uzturēt attiecīgo mìtni, nodrošināt nepieciešamo pakalpojumu sniegšanu, kā arī iespēju izmantot attiecīgos infrastruktūras objektus (piem., bērnu uzraudzī̌sanas vietas un sporta iekārtas). ${ }^{68}$

Nobeigumā vēl jānorāda uz Vācijas juridiskajā literatūrā atzīto, ka - salīdzinājumā ar hipotēku - reālnasta ir daudz piemērotāka ilgtermina saistības izpildījumu "vērtības nodrošināšanai” ne tikai tāpēc, ka reālnastas izpildījumi var izpausties arī kā dažādu lietu (naturāliju) devumi vai pakalpojumu sniegšana, bet jo īpaši tāpēc, ka nav nepieciešams, lai atsevišḳie reālnastas izpildījumi jau iepriekš būtu noteikti pilnīgi precīzi

57 Sk.: Schmid / Hürlimann-Kaup, N 1442; Riemer H. M. Die Beschränkten dinglichen Rechte. 2. Aufl. Bern: Stämpfli Verlag, 2000, \$ 37 N 4 (turpmāk - Riemer, \$ 37 N 4); Binder, Rz 9/5.

58 Sk.: Tuor /Schnyder /Schmid /Jungo, \$ 110 N 13; ZGB Kommentar / Flück, Art. 782, N 7.

59 Sk.: MüKoBGB /Mohr, \$ 1105, Rn. 26.

60 Sk.: Schmid / Hürlimann-Kaup, N 1442; Hrubesch-Millauer S., Graham-Siegenthaler B., Roberto V. Sachenrecht. 5. Aufl. Bern: Stämpfli Verlag, 2017, N 08. 144.

61 Sk.: Tuor /Schnyder /Schmid /Jungo, S 110 N 13; ZGB Kommentar /Flück, Art. 782, N 7; Riemer, \ 37 N 4; MüKoBGB /Mohr, \ 1105, Rn. 26; Vieweg /Werner, \ 16, Rn. 72.

62 Sk.: MüKoBGB /Mohr, \$ 1105, Rn. 18.

63 Sk.: MüKoBGB /Mohr, \$ 1105, Rn. 26; Palandt /Herrler, \$ 1105, Rn. 4.

64 Sk.: Tuor /Schnyder / Schmid /Jungo, \$ 110 N 15; Schmid / Hürlimann-Kaup, N 1442; ZGB Kommentar /Flück, Art. 782, N 7; Riemer, \$ 37 N 4; Binder, Rz 9/5; MüKoBGB / Mohr, \$ 1105, Rn. 26.

65 Sk.: Palandt /Herrler, \$ 1105, Rn. 4.

66 Sk.: MüKoBGB /Mohr, \$ 1105, Rn. 26, 32.

67 Sk.: Tuor / Schnyder /Schmid /Jungo, \$ 110 N 16; Riemer, \ 37 N 4.

68 Sk.: Binder, Rz 9/5. 
(piem., konkrētas naudas summas veidā). Lai uzturētu atsevišķo izpildījumu vērtību, reālnastai var tikt piesaistìta arī "vērtïbas nodrošināšanas klauzula", t. sk. pielīgstot atsevišķo izpildijjumu apmēra automātisku pielāgošanos jaunajiem apstāklıiem, ${ }^{69}$ un, ņemot vērā naudas vērtỉbas pastāvīgo pazemināšanos, reālnastas institūts atkal ir kḷuvis aktuāls. $^{70}$ Turklāt šis institūts no jauna ir ieguvis nozīmi mūsdienu privāttiesiskajā apgrozībā, arī pateicoties reālnastas principiālajai "fleksibilitātei", kas nodrošina daudzveidīgu tās praktisko izmantojumu. ${ }^{71}$ No Latvijas tiesību viedokl̦a minēto praktisko nozìmigumu vēl vairāk paspilgtina reālnastas liettiesiskā noturỉba, jo, kā jau norādìts iepriekšs, pat piedziņas vēršana uz kalpojošo nekustamo īpašumu pēc vispārīgā principa neizbeidz reālnastu un tā saista nekustamā īpašuma jauno ieguvēju (sk. CL 1261., 1262., 2088. p.).

\section{Kopsavilkums}

Kaut arī reālnasta vēsturiski ir izveidojusies kā feodālo tiesību institūts, tā nebūt nav vērtējama kā "arhaisks" vai kā mūsdienu privāttiesiskās apgrozības prasībām neatbilstošs lietu tiesību institūts. Gluži pretēji, ņemot vērā reālnastas būtību (tās liettiesisko prioritāti un noturību), reālnastas piemērotību ne tikai saistībtiesisku prasījumu liettiesiskai nodrošināšanai, bet arī atkārtoti dodamo izpildījumu "vērtības nodrošināšanai”, kā arī daudzveidību, kādā saturiski var izpausties reālnastas izpildījumi, mūsdienu Latvijas praksē šim lietu tiesību institūtam pavisam droši var būt pietiekami būtiska nozīme. To cita starpā apliecina rakstā aplūkotie tipiskie piemēri no Latvijas un citu germāṇu tiesību sistēmas valstu (Vācijas, Austrijas, Šveices) prakses, kas uzskatāmi atspoguḷo reālnastas institūta lietojuma daudzveidīgumu un praktisko noderīgumu mūsdienu privāttiesiskajā apgrozībā. Turklāt minēto ārvalstu juridiskās prakses tendences var būt noderīgs paraugs un vienlaikus arī pamudinājums pārṇemt šo citu valstu pozitīvo pieredzi un iedzīvināt to mūsu nacionālajās tiesībās.

\section{BIBLIOGRĀFIJA}

\section{Literatūra}

1. Binder M. Sachenrecht. Wien: Verlag Österreich, 2003.

2. Blaese H., Mende S. Das Sachenrecht. Lettlands Zivilgesetzbuch vom 28. januar 1937 in Einzeldarstellungen. Bd II, 2. Riga: Verlag der AG “Ernst Plates”, 1940.

3. von Bunge F. G. Das liv- und esthländische Privatrecht. Theil I: Einleitung, Personen-, Sachenund Forderungenrecht. 2. Aufl. Reval: Verlag von Franz Kluge, 1847.

4. Čakste K. Civiltiesỉbas. Lekcijas. Raksti. Rīga: Zvaigzne ABC, 2011.

5. Demharter J. Grundbuchordnung. 31. Aufl. München: Verlag C. H. Beck, 2018.

6. Erdmann C. System des Privatrechts der Ostseeprovinzen Liv-, Est- und Curland. Bd. II. Sachenrecht. Riga: N. Kymmel's Verlag, 1891.

69 Sk.: MüKoBGB / Mohr, $\mathbb{S} 1105$, Rn. 33.

70 Sk.: Jauernig O. (Begr.) Bürgerliches Gesetzbuch. Kommentar. 17. Aufl. München: Verlag C. H. Beck, 2018, SS 1105-1108, Rn. 1.

${ }^{71}$ Sk.: Prütting H. Sachenrecht. 36. Aufl. München: Verlag C. H. Beck, 2017, Rn. 946. 
7. Gaier R. (red.). Münchener Kommentar zum Bürgerlichen Gesetzbuch. Bd. 7. Sachenrecht (SS 854-1296). WEG. ErbbauRG. 7. Aufl. München: Verlag C. H. Beck, 2017.

8. Grūtups A., Kalniņš E. Civillikuma komentāri. Trešā daḷa. Lietu tiesības. Īpašums. 2. izd. Rīga: Tiesu namu aǵentūra, 2002.

9. Gulbis R. Pienākums segt dzīvojamās mājas pārvaldīšanas izdevumus un norēḳināties par pakalpojumiem, kas saistīti ar dzīvokḷa īpašuma lietošanu: reālnastas tiesiskā regulējuma attiecināšana kā risinājums. Grām.: Latvijas Republikas Satversmei - 95. Latvijas Universitātes 75. zinātniskās konferences rakstu krājums. Rīga: LU Akadēmiskais apgāds, 2017, 123.-132. lpp.

10. Hrubesch-Millauer S., Graham-Siegenthaler B., Roberto V. Sachenrecht. 5. Aufl. Bern: Stämpfli Verlag, 2017.

11. Iro G. Sachenrecht. 6. Aufl. Wien: Verlag Österreich, 2016.

12. Jauernig O. (Begr.). Bürgerliches Gesetzbuch. Kommentar. 17. Aufl. München: Verlag C. H. Beck, 2018.

13. Konradi F., Valters A. (sast.). Civillikumi ar paskaidrojumiem. Otrā grāmata. Lietu tiesības. Rìga: "Grāmatrūpnieks" izdevums, 1935.

14. Konradi F., Zvejnieks T. (sast.). Civilprocesa likums (1938. g. izd., 1939. g. iespied.) ar paskaidrojumiem. Rīga: Valsts tipogräfijas izdevums, 1939.

15. Kostkiewicz J. K., Wolf S., Amstutz M., Fankhauser R. (Hrsg.). ZGB Kommentar. 3. Aufl. Zürich: Orell Füssli Verlag, 2016.

16. Koziol H., Bydlinski P., Bollenberger R. (Hrsg.). Kurzkommentar zum ABGB. 5. Aufl. Wien: Verlag Österreich, 2017.

17. Neilands R. Reālnastu arhaisms. Jurista Vārds, 06.03.2018., Nr. 10 (1016), 24.-29. lpp.

18. Palandt O. (Begr.). Bürgerliches Gesetzbuch. 78. Aufl. München: Verlag C. H. Beck, 2019.

19. Prütting H. Sachenrecht. 36. Aufl. München: Verlag C. H. Beck, 2017.

20. Riemer H. M. Die Beschränkten dinglichen Rechte. 2. Aufl. Bern: Stämpfli Verlag, 2000.

21. Rozenfelds J. Lietu tiesības. 4. izd. Rīga: Zvaigzne ABC, 2011.

22. Rozenfelds J. Pētījums par Civillikuma Lietu tiesību daḷas (ceturtās, piektās, sestās un septītās nodaḷas) modernizācijas nepieciešamību (2008). Pieejams: http://at.gov.lv/lv/resursi/ petijumi.

23. Schmid J., Hürlimann-Kaup B. Sachenrecht. 5. Aufl. Zürich, Basel, Genf: Schulthess, 2017.

24. Sinaiskis V. Latvijas civiltiesību apskats. Lietu tiesības. Saistību tiesības. Rīga: Latvijas Juristu biedrība, 1996.

25. Sinaiskis V. Saimniecības tiesību lietiskās normas. Tieslietu Ministrijas Vēstnesis, 1935, Nr. 4, 657.-743. lpp.

26. Tuor P., Schnyder B., Schmid J., Jungo A. Das Schweizerische Zivilgesetzbuch. 14. Aufl. Zürich, Basel, Genf: Schulthess, 2015.

27. Vieweg K., Werner A. Sachenrecht. 8. Aufl. München: Verlag Franz Vahlen, 2018.

28. Vinzzarājs N. Lietu tiesība. Tieslietu Ministrijas Vēstnesis, 1938, Nr. 2, 432.-447. lpp.

29. Višņakova G., Balodis K. Latvijas Republikas Civillikuma komentāri. Lietas. Valdījums. Tiesības uz svešu lietu (841.-926., 1130.-1400. p.). Rìga: Mans Īpašums, 1998.

30. Weber R. Sachenrecht II. Grundstücksrecht. Baden-Baden: Nomos Verlagsgesellschaft, 2005.

31. Zobl D. Grundbuchrecht. 2. Aufl. Zürich, Basel, Genf: Schulthess, 2004. 
32. Буковский В. (сост.). Сводъ гражАанскихъ узаконений губерний Прибалтийскихъ (съ продолжениемъ 1912-1914 г. г. и съ разъяснениями въ 2 томахъ). Т. І. Введение, Право семейственное, Право вещное и Право наследования. Рига: Г. Гемпель и Ко, 1914.

33. Буковский В. (сост.). Сводъ гражАанскихъ узаконений губерний Прибалтийскихъ (съ продолжениемъ 1912-1914 г. г. и съ разъяснениями въ 2 томахъ). Т. ІІ. Право требований. Рига: Г. Гемпель и Ко, 1914.

34. Тютрюмовъ И. М. ГражАанское право. ИзА. 2. Тарту: Типография Г. Ааакманъ, 1927.

\section{Juridiskā prakse}

35. Augstākās tiesas 1929. gada 27. februāra spriedums Nr. 167. Latvijas Senāta spriedumi (1918-1940). 11. sēj. Senāta Civilā kasācijas departamenta spriedumi (1928-1929). Faksimilizdevums. Rīga: Latvijas Republikas Augstākā tiesa, Senatora Augusta Lēbera fonds, 1998, 4484.-4485. lpp.

36. Augstākās tiesas 1933. gada 13. decembra spriedums Nr. 930. X Izvilkumi no Latvijas Senāta Civilā kasācijas departamenta spriedumiem. Sastādỉjuši: senators F. Konradi un Rīgas apgabaltiesas loceklis A. Valters. Riga: izdevnieciba "Jurists" / izdevnieciba "Grāmatrūpnieks", 1933/1934, 159.-160. lpp.

37. Augstākās tiesas 1934. gada 23. februāra spriedums Nr. 619. X Izvilkumi no Latvijas Senāta Civilā kasācijas departamenta spriedumiem. Sastādījuši: senators F. Konradi un Rīgas apgabaltiesas loceklis A. Valters. Rigga: izdevniecỉba "Jurists" / izdevniecība "Grāmatrūpnieks", 1933/1934, 287. lpp.

38. Augstākās tiesas 1938. gada 24. maija spriedums Nr. 475. Latvijas Senāta spriedumi (19181940). 14. sēj. Senāta Civilā kasācijas departamenta spriedumi (1937-1940). Faksimilizdevums. Rīga: Latvijas Republikas Augstākā tiesa, Senatora Augusta Lēbera fonds, 1998, 5547.-5548. lpp.

39. Augstākās tiesas Senāta 2012. gada 4. oktobra lēmums lietā Nr. SKC-1702/2012 (C01199611). Nav publicēts.

40. Augstākās tiesas Civillietu tiesu palātas 2012. gada 11. decembra lēmums lietā Nr. C01199611. Nav publicēts.

41. Augstākās tiesas 2014. gada 30. janvāra lēmums lietā Nr. SKC-1479/2014 Pieejams: http:// at.gov.lv/lv/judikatura/judikaturas-nolemumu-arhivs.

42. Rīgas apgabaltiesas 2018. gada 10. maija spriedums lietā Nr. C31362815. Pieejams: https:// manas.tiesas.lv/eTiesasMvc/nolemumi. 